Jurnal ASPIKOM, Vol. 7, No. 1, January 2022, pp. 71-83

P-ISSN: 2087-0442, E-ISSN: 2548-8309

DOI: http://dx.doi.org/10.24329/aspikom.v7i1.1069

\title{
Application of User Generated Content by Television News' during Pandemic
}

\author{
Rahmatul Furqan*, Sitti Murniati Muhtar, Nosakros Arya \\ Universitas Hasanuddin, Jl Perintis Kemerdekaan Makassar, Sulawesi Selatan, \\ Indonesia \\ *Corresponding author, e-mail: rahmatul.furqan@unhas.ac.id
}

\begin{abstract}
The revolution of technology has always shaped the works of journalism, including the news content and its relationship with the public. Along with the digital era, people started to participate in and contribute to journalism. User Generated Content (UGC) has regularly altered both information flows and the nature of news work for the mainstream media. By conducting a qualitative content analysis, this study tries to examine the use of UGC by 24-hour news TV channels in Indonesia in relation to the context of participatory journalism in the Covid-19 pandemic situation. The results of this study indicate that four 24-hour TV news channels in Indonesia are beginning to negotiate most of their 'professional logic' towards the logic of 'adaptation'. Overall, framing analysis shows that news TV stations' use of UGC has not optimally encouraged more constructive pandemic journalism practices.
\end{abstract}

Keywords: Covid-19; Participatory Journalism; Pandemic; UGC

\begin{abstract}
Abstrak
Revolusi teknologi selalu mempengaruhi karya jurnalitik, baik dari segi konten maupun relasinya dengan publik. Di era digital, masyarakat mulai berpartisipasi dan berkontribusi dalam jurnalisme dengan cara yang berbeda. User Generated Content (UGC) telah mengubah arus informasi dan sistem kerja pada media arus utama. Dengan melakukan analisa konten secara kualitatif, penelitian ini mencoba mengkaji penggunaan UGC oleh saluran TV berita 24 jam di Indonesia, kaitanya dengan konteks jurnalisme partisipatif pada situasi Pandemi Covid19. Hasil penelitian ini menunjukkan bahwa empat saluran berita TV 24 jam di Indonesia mulai menegosiasikan sebagian besar 'logika profesional' mereka ke arah logika 'adaptasi dan keterbukaan'. Secara bersamaan, analisis framing menunjukkan bahwa penggunaan UGC oleh stasiun TV berita tersebut belum sepenuhnya mendorong praktik jurnalisme pandemi yang lebih konstruktif.
\end{abstract}

Kata Kunci: Covid-19; Journalisme Partisipatif; Pandemi; UGC 


\section{Introduction}

On April 13, 2020, the President of the Republic of Indonesia, Joko Widodo, declared the Covid-19 pandemic a national disaster. In conditions of uncertainty during a disaster (pandemic), the role of the media is increasingly needed to meet information needs, both for the government and the general public. Information from the media can help various levels of society to understand the disaster or pandemic that has occurred so that they can take the right attitude in dealing with the situation. The media has social responsibility in conveying accurate and ethical information in times of disaster to avoid confusion among the public (Budi, 2012; Lestari, 2019).

Journalism during the pandemic itself needs to combine the practice of health journalism, disaster journalism, and empathy journalism (Hayati \& Yoedtadi, 2020). As with the concept of disaster journalism in general, journalism during a pandemic must prioritize information related to the pandemic control process and encourage solutions to suppress the spread of the virus and minimize the risk to victims (Haddow \& Haddow, 2013). From the point of view of empathy journalism, reporting during a pandemic must avoid sensationalism and promote constructive information by prioritizing human values (Parahita, 2020). During a pandemic, journalism is expected to provide information in accordance with the facts on the ground, with in-depth data, and presented objectively (Hayati \& Yoedtadi, 2020). How the media frames information related to the COVID-19 pandemic will affect the public's reaction to the crisis (Woda, Birowo, Vidiadari, \& Nuswantoro, 2021).

On the other hand, the pandemic has brought significant changes and major challenges for journalists' work (Perreault \& Perreault, 2021; Vinanda, 2021). Journalists' access to some news sources is increasingly restricted, especially when the Government's Large-Scale Social Restrictions (PSBB) and Community Activity Restrictions (PPKM) are implemented to prevent the spread of the deadly Covid-19 virus. Some vital news sources covering the pandemic, such as hospitals, especially quarantine isolation rooms, are not accessible for journalists to reach. Likewise, access to information from medical personnel is difficult to obtain. In this situation, the active participation of citizens in collecting, reporting, analyzing, and disseminating news and information is increasingly needed. Jay Rosen, Professor of Journalism from New York University, termed this the practice of participatory journalism (Domingo et al., 2008).

The development of the concept of participatory journalism, also known as citizen journalism, cannot be separated from the influence of technological advances. It does not only affects the production process of news but also changes the distribution pattern to the consumption of news (Cottle \& Ashton, 1999). In today's digital era, people are starting to participate actively and contribute to the practice of journalism in a different way than usual (Colistra, Buchman, \& Duvall, 2017). For example, technology now allows the production of videos or photos at a much more affordable cost and easier to operate without requiring special skills. Everyone with a video camera or smartphone can now visualize their story and share it through social networking sites(Bock, 2012). Any photo, video, audio, or idea was taken by the general public, or amateur journalists who are not affiliated with a news organization is called user-generated content (UGC) (Colistra et al., 2017). As well, Daugherty, Eastin, and Bright (2008) define UGC as any content voluntarily contributed by the general public or not from professional journalists.

This study wants to examine how television media in Indonesia uses UGC in the context of participatory journalism, which allows the general public to contribute 
content, especially in a pandemic situation. UGC utilization by mainstream media such as television itself is not something new. The existence of UGC is believed to be beneficial both for citizens as content creators and for the media industry itself. As explained byAhva and Hellman (2015), the public is motivated to create content and share their stories from their own point of view or perspective, while professional journalists also use UGC to practice a more democratic concept of journalism. UGC enables journalists to enrich their coverage with more diverse perspectives (Matthews, 2013). At this point, the general public can also play the role of journalists through UGC. Wardle, Dubberley, and Ma Pete Brown (2014) presented that journalists no longer dominate footage or information data because the general public now can tell their stories directly to the public by utilizing the latest technological sophistication. Especially in critical times such as in the Covid-19 Pandemic situation, UGC has more significant potential to be utilized by the media industry.

Until now, the use of UGC by mainstream media still invites a number of criticisms. Some media experts view UGC as a threat to mainstream media. Clark (2009) claims, "amateurism can become a dangerous substitute for trained, responsible behavior" (paragraph 7). Citizen journalists are untrained, less credible, and lack knowledge covering the field (Colistra et al., 2017). Simultaneously, UGC uploads also raise suspicion among professional media regarding the motive for making UGC in a crisis because it can be a way for them to manipulate stories and promote certain agendas.(Wahl-Jorgensen, Williams, \& Wardle, 2010). Meanwhile, one of the reasons the editors continue to use UGC is the urge to get footage as quickly as possible, right at the time of an incident. Pamela and Stephen (1996) explained that ordinary people could offer content recorded directly from where a moment occurs with technology in their hands.

With the demands of breaking news on TV stations that broadcast news almost 24 hours, sources of information from amateur recordings can help speed up information delivery (Van der Haak, Parks, \& Castells, 2012). This is proven by the intensity of user-generated content (UGC) by news television stations in Indonesia, which is increasing during the Covid-19 pandemic. Amateur videos circulating online give viewers a first-hand view of the development of the pandemic situation, from the activities of medical personnel in hospitals self-isolation activities for Covid-19 patients to community dynamics after the implementation of PSBB or PPKM. Rapidly, amateur videos on these networking sites then turned to the small screen, presented in the form of news packages which were then broadcast on various news programs on news TV stations. UGC presents direct information from locations that are difficult for journalists to access during the pandemic, especially during the implementation of PSBB to PPKM. For TV stations that focus on news programs, such as Metro TV, TV One, or CNN Indonesia and Kompas TV, the use of UGC is becoming more frequent. In fact, amateur photos or video recordings from the internet can be used multiple times by different news programs on the same day. Some of the amateur content can even become headlines or headlines. UGC has become an integral element of journalism, being the main source of news headlines and up-to-date news.

On the other hand, pursuing the speed of news also has consequences because it often contradicts the main function of journalism, namely verification (Rauchfleisch, Artho, Metag, Post, \& Schäfer, 2017). Zeller and Hermida (2015, p. 111) stressed that verification is an important element of journalism practice because it is a "normative practice in which journalism seeks to distinguish itself from other forms of public 
communication". Especially in pandemic reporting, the circulation of information is not only required to be fast but also must be valid (Perreault \& Perreault, 2021). Faced with this challenge, most news organizations claim that they can guarantee verification for all UGC materials they use (Rauchfleisch et al., 2017; Sushmita, Pawito, \& Rahmanto, 2021). However, in crises such as pandemics, $24 / 7$ news channels tend to compromise or sometimes even neglect the process of identifying and verifying information (Rauchfleisch et al., 2017). Again, the main reason is that newsrooms on 24/7 news channels are under pressure to broadcast immediately, to report breaking news (Wardle et al., 2014).

However, some experts argue that the level of trust in news is no longer only determined by the verification of facts or sources but is also influenced by the level of authenticity or originality and direct narratives from people who experience/witness an incident in the field (Bock, 2012). UGC has the potential to present direct testimony from sources in locations that can be confirmed (Bock, 2012, p. 644). For some audiences, UGC is considered more honest and persuasive because eyewitnesses are real participants of the crisis situation and subjectively report the event from their own point of view, rather than a professional journalist who acts as an observer and is obliged to testify objectively (Bock, 2012, p. 649).

On the other hand, the pessimistic view argues that "subjectivity" will prevent the audience from understanding the overall context of the crisis because the stories presented by UGC are only limited to their personal experiences or perspectives and ignore other factors that reveal the general picture of a crisis. As a result, UGC may form what Chouliaraki calls "adventure news" which means that moral or ethical attitudes are absent from the content of crisis reporting (Tait, 2008). On the other hand, other experts also argue that the subjective testimony offered by UGC can appeal to the audience's emotions more effectively than professional recordings. Williams, WahlJorgensen, and Wardle (2011) explain that the authenticity of the stories presented through UGC can strengthen audience engagement because viewers can see crisis events from the perspective of those affected or those who were at the crisis site and witnessed the crisis first-hand. Therefore, it can be argued that amateur footage plays an important role in shaping how the public recognizes and reacts to a crisis (Ahva \& Hellman, 2015).

A number of studies have been conducted to evaluate the use of UGC by the mainstream media. However, no research focuses on analyzing the use of UGC by mainstream media during the Covid-19 pandemic crisis in Indonesia. This study discusses the implications of the dependence of media organizations, especially news television stations, on content created by citizens in crises, especially during a pandemic. The aims of this research are; first, to see the extent of 24-hour news TV in Indonesianegotiate the "logic of professionalism" "they become the logic of "adaptability and openness" as the views of optimism and pessimism of the use of UGC have been discussed previously; second, to see to what extentthe concept of participatory journalism through the use of UGC can realize the hope of an ideal pandemic journalism practice by news TV media in Indonesia.

\section{Method}

This study uses a content analysis method with a qualitative approach. This method is used in accordance with the purpose of the research, namely to provide an understanding of the use of UGC by mainstream media and its implications for 
constructive journalism practices during a pandemic. The qualitative approach allows this study to be carried out in more depth on the data considered by the researcher.

The main source in this research is video coverage of news related to the pandemic by news television stations in Indonesia that use UGC. The subjects of this research are television stations whose broadcasts are dominated by news broadcasts or news tv channels in Indonesia, including TV One, Metro TV, CNN Indonesia, and Kompas TV. The data collection technique used is observation and documentation, with the limitation of the research period during the initial period of determining PPKM by the government, which is June 22 to July 30, 2021. The main data is obtained by collecting news shows uploaded on the YouTube channel of each news TV station. Researchers used a purposive sampling technique by randomly selecting two news videos containing coverage of the pandemic using UGC on each news TV station. Thus, the sample in this study was eight videos.

Table 1. UGC Content which Airs on TV News in Indonesia and becomes the Research Sample

\begin{tabular}{cllc}
\hline No & \multicolumn{1}{c}{ UGC Content } & Release Date & News TV \\
\hline 1 & $\begin{array}{l}\text { Viral Ruang Isolasi Tak Ada Nakes } \\
\text { (Viral Isolation Room with No }\end{array}$ & July 22, 2021 & CNN Indonesia \\
& Healthcare Staff) & & \\
\hline 2 & $\begin{array}{l}\text { Antrian Pasien Covid 19 di RSKD } \\
\text { Hingga Koridor (The queue of Covid } \\
19 \text { patients at the RSKD to the } \\
\text { Corridor) }\end{array}$ & July 3 2021 & Kompas TV \\
\hline 3 & $\begin{array}{l}\text { (Pasien Covid Diusir Warga) } \\
\text { Residents Expelled Covid Patients }\end{array}$ & June 2, 2021 & Metro TV \\
\hline 4 & $\begin{array}{l}\text { Kakek Kayuh Sepeda 15 Km untuk } \\
\text { Vaksin (Grandpa Paddles a Bike } \\
\text { 15Km for Vaccines) }\end{array}$ & 30 July 2021 \\
\hline 5 & $\begin{array}{l}\text { Warga Disuntik Vaksin Tak Ditekan } \\
\text { (Resident is Getting Injected without }\end{array}$ & July 15 2021 & CNN Indonesia \\
& Pressed) & & \\
\hline 6 & $\begin{array}{l}\text { Pasien Positif Covid 19 Dianiaya } \\
\text { Warga di Toba Sumut (Covid 19 } \\
\text { Positive Patients Persecuted by } \\
\text { Residents in Toba Sumut) }\end{array}$ & July 27 2021 \\
\hline 7 & $\begin{array}{l}\text { Ketua DPRD Ketapang Joged Tanpa } \\
\text { Prokes (Chairman of the DPRD } \\
\text { Ketapang danced Without Health } \\
\text { protocol) }\end{array}$ & 19 July 2021 & Metro TV \\
\hline 8 & $\begin{array}{l}\text { Ambil Paksa Jenazah di Bondowoso, } \\
\text { Warga Bakar Peti Jenazah? } \\
\text { (Forcefully Taking Bodies in } \\
\text { Bondowoso, Residents Burn } \\
\text { Coffins?) }\end{array}$ & July 18 2021 & TV One \\
\hline & & & \\
\hline
\end{tabular}

Meanwhile, secondary sources are the results of studies by other researchers that describe, analyze, and/or evaluate information relevant to the research. Referring to secondary sources, the researcher examines the extent to which newsrooms in research 
subjects begin to negotiate their "professional logic" into a logic of "adaptability and openness" (McCosker, 2013) with an assessment based on the following categorization.

Table 2. Categorization of Professionalism Logic and Adaptability Logic

\begin{tabular}{lll}
\hline No & Professional Logic & The Logic of Adaptability and Openness \\
\hline 1 & Objectivity: & Authenticity: \\
& $-\quad$ There is verification to other & $-\quad$ Domination by the voices of \\
& relevant sources & residents who experienced the \\
& $-\quad$ Based on data and facts & incident first-hand \\
& & $-\quad$ Emotional \\
\hline 2 & Professional Engineering Quality & Amateur Engineering Quality \\
\hline
\end{tabular}

Furthermore, to examine the extent to which the use of UGC by news TV can encourage the constructive practice of pandemic journalism, the researcher also conducted a framing analysis or news framing. The categorization for this framing analysis is carried out by referring to the concepts of health journalism, disaster, empathy journalism that have been discussed previously. The categorization of constructive and destructive news framing is as follows.

Table 3. Categorization of Constructive and Destructive News Framing

\begin{tabular}{cll}
\hline No & \multicolumn{1}{c}{ Constructive Framing } & \multicolumn{1}{c}{ Destructive Framing } \\
\hline 1 & Solution-oriented & Conflict oriented \\
\hline 2 & $\begin{array}{l}\text { Public orientation/ strengthening } \\
\text { or empowerment }\end{array}$ & Sensational \\
\hline 3 & Inclusiveness and diversity & Focus on negative consequences \\
\hline 4 & Empathy and solidarity & $\begin{array}{l}\text { Generate fear and increase } \\
\text { uncertainty }\end{array}$ \\
\hline
\end{tabular}

\section{Results and Discussion}

\section{The Logic of Professionalism Vs the Logic of Adaptability}

Based on the analysis conducted, the entire sample of this study shows a partial shift in the logic of professionalism to the logic of adaptability by 24-hour news TV stations in Indonesia in broadcasting UGC, as illustrated in the following table.

Table 4. The Results of the Analysis of the Use of UGC by News TV Stations in Indonesia

\begin{tabular}{lllccc}
\hline No UGC Content & News TV & $\begin{array}{c}\text { Verification to } \\
\text { direct } \\
\text { eyewitnesses }\end{array}$ & $\begin{array}{c}\text { Other } \\
\text { resource } \\
\text { persons }\end{array}$ & Current & $\begin{array}{r}\text { Emotional } \\
\text { Amateur } \\
\text { technical } \\
\text { quality }\end{array}$ \\
\hline & & & & & \\
1 & $\begin{array}{l}\text { Viral } \\
\text { Isolation } \\
\text { Room No } \\
\text { Healthcare }\end{array}$ & $\begin{array}{l}\text { CNN } \\
\text { Indonesia }\end{array}$ & $\mathrm{V}$ & $\mathrm{V}$ & $\mathrm{V}$ \\
\hline & $\begin{array}{l}\text { The queue } \\
\text { of Covid } \\
19 \text { patients }\end{array}$ & $\begin{array}{l}\text { Kompas } \\
\text { TV }\end{array}$ & $\mathrm{V}$ & $\mathrm{V}$ & $\mathrm{V}$ \\
\hline
\end{tabular}




\begin{tabular}{|c|c|c|c|c|c|c|c|}
\hline & $\begin{array}{l}\text { at the } \\
\text { RSKD to } \\
\text { the } \\
\text { Corridor }\end{array}$ & & & & & & \\
\hline 3 & $\begin{array}{l}\text { Residents } \\
\text { Expelled } \\
\text { Covid } \\
\text { Patients } \\
\end{array}$ & Metro TV & & V & V & V & V \\
\hline 4 & $\begin{array}{l}\text { Grandpa } \\
\text { Paddles a } \\
\text { Bike } 15 \mathrm{Km} \\
\text { for } \\
\text { Vaccines }\end{array}$ & $\begin{array}{l}\text { Kompas } \\
\text { TV }\end{array}$ & V & V & V & V & V \\
\hline 5 & $\begin{array}{l}\text { Residents } \\
\text { Are } \\
\text { Injected } \\
\text { with } \\
\text { Unsuppress } \\
\text { ed } \\
\text { Vaccines }\end{array}$ & $\begin{array}{l}\mathrm{CNN} \\
\text { Indonesia }\end{array}$ & & V & V & & V \\
\hline 6 & $\begin{array}{l}\text { Covid } 19 \\
\text { Positive } \\
\text { Patients } \\
\text { Persecuted } \\
\text { by } \\
\text { Residents } \\
\text { in Toba } \\
\text { Sumut }\end{array}$ & TV One & V & V & V & V & V \\
\hline 7 & $\begin{array}{l}\text { Chairman } \\
\text { of the } \\
\text { DPRD } \\
\text { Ketapang } \\
\text { danced } \\
\text { Without } \\
\text { Prokes }\end{array}$ & Metro TV & & V & V & & V \\
\hline 8 & $\begin{array}{l}\text { Forcefully } \\
\text { Taking } \\
\text { Bodies in } \\
\text { Bondowos } \\
\text { o, } \\
\text { Residents } \\
\text { Burn } \\
\text { Coffins? }\end{array}$ & TV One & & & V & & V \\
\hline
\end{tabular}

All UGC samples in this study were broadcast on the same day the content went viral on social media. This shows that news TV stations are really chasing speed or actuality. However, to complement the UGC broadcast in the news package, there is no verification or re-interview of eyewitnesses in the field or who are the main sources in UGC. For example, at the UGC entitled "Covid Patients Expelled by Residents," which was broadcast by Metro TV, residents who vented through their social media content were not re-interviewed by journalists to find out more details or re-clarified their 
experiences. Likewise, the broadcast of the UGC entitled "Chairman of the DPRD Ketapang danced Without Health Protocol" by TV One also did not ask for clarification from the Chairperson of the DPRD, who was the subject of the news.

Nevertheless, the results of this study show that 24-hour news TV stations in Indonesia are still trying to apply the principle of covering both sides in broadcasting news originating from UGC by presenting several additional sources to explain the viral UGC. Clarification was also carried out to ensure the truth of the content that started circulating or viral on social media regarding the development of the pandemic. In this case, TV stations are sufficient to show awareness of the importance of presenting verified news to not cause turmoil due to hoaxes regarding pandemic issues. For example, CNN broadcasted "Viral Isolation Room with No Health Staff". CNN broadcasted an amateur video recorded in an isolation room without nurses or doctors at the Darsono Doctors Regional Hospital, Pacitan, East Java. To clarify the alleged neglect of the patient in the isolation room, CNN also completed its news package with a video clarification or interview with Hendra Purwaka as Acting Head of the Pacitan District Health Service. In pandemic reporting, journalists must not only present information quickly but also must present it based on facts on the ground to avoid disinformation.

Observations in this study also show that the overall UGC shown in pandemic reports on news TV stations looks amateurish. For example, the video footage taken by the residents looks 'shaky' and 'out of focus', far from the impression or criteria of a professional video. For example, the news video titled "Covid 19 Patient Queue at the RSKD to the Corridor," which Kompas TV broadcasted on July 3, 2021, shows footage of residents showing the conditions and situation at the Kantjuso Djatiwibowo hospital. The video contains amateur footage in portrait video format recorded using a regular mobile camera. The audio or sound in the video cannot be heard clearly, and the shooting technique is shaky, out of focus, far from having a professional impression.

In general, TV stations place great importance on the best picture quality. Journalists are also specially trained on shooting techniques and audio settings during coverage in order to produce professional video quality. However, as it turned out, the element of professionalism was ruled out and excluded for video recordings covered by residents. This is because the videos were recorded by ordinary citizens who did not receive special training in journalism or shooting techniques. However, such an amateurish quality is important for making videos appear spontaneous and therefore more authentic, realistic, and honest than video packages shot by professional journalists that seem more staged and manipulated, as suggested byAhva and Hellman (2015).

Amateur footage that has gone viral on the internet and re-aired by mainstream TV stations shows honest footage directly from the point of view of the people at the scene or who experienced an incident. For instance, UGC broadcast by Metro TV displayed a resident in self-isolation and was evicted by residents located in Batununggal District, Bandung, West Java. The UGC, which was on June 24, aired emotional stories from residents who were victims of expulsion. 


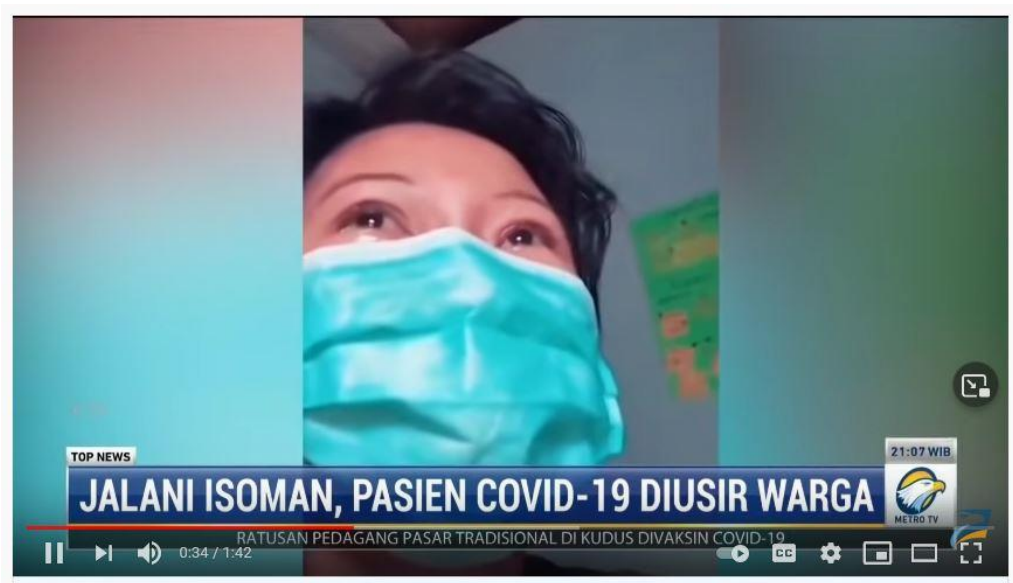

Figure 1. UGC footage showing a covid patient who is self-isolating and being expelled by residents, located in Batununggal District, Bandung, West Java, and broadcast by Metro TV on June 24, 2021

The UGC video footage in Figure 1 not only presents live footage from the first party. At the same time, it shows the honest emotions of the evicted victims and the quality of this kind of footage, Andén-Papadopoulos (2013). In fact, it has a higher level of trustworthiness than recorded news packages by professional journalists. According to Andén-Papadopoulos (2013), the level of trustworthiness of news today is no longer limited to relying on the verification of sources and facts but also by the sincerity of emotions that appear. In the video example above, the victim speaks directly to the camera, telling the discrimination that she has experienced while bursting into tears. This subjective point of view is rarely brought up by mainstream news narratives because professional reporters must report objectively and are not expected to involve emotions or feelings in reporting the news as it is conveyed by Bock (2012, p. 649). Therefore, it can be said that amateur recordings used in pandemic reporting can be more persuasive and can be more easily trusted by the public to play an important role in shaping how the public recognizes and reacts to pandemic conditions. As delivered by Couldry (2012, p. 194), amateur recordings can encourage the creation of moral responsibility by the public as audiences to explore further the problems faced by "distant others" or, in this case, the object of pandemic reporting. This means that audiences are more likely to empathize with emotional amateur recordings than mainstream news packages with professional logic.

\section{News Framing}

The results of this study indicate that the presence of UGC in mainstream media such as news TV in Indonesia encourages more inclusive and diverse news content. Information or facts regarding the current pandemic are not only present/born from groups of experts or figures who have high prominence but also come directly from ordinary citizens who produce UGC as well as main eyewitnesses. This inclusiveness contributes constructively to efforts to democratize the handling of crises such as the Covid-19 pandemic. Through amateur content uploaded to cyberspace, the general public can actively encourage various government policies or political action regarding the Covid-19 pandemic. This is well recognized by a number of parties who create amateur content and tell the impact of the Covid-19 pandemic on the dynamics of their daily lives. When mainstream media use amateur content, it will help their aspirations 
or stories to be heard by a wider audience, helping their "voice" to be heard more and their existence more "seen". The democratization of the media in times of health crises like this is very much needed, especially to voice any inequality or injustice that has arisen regarding the handling of the pandemic in the field. As stated by Nwakpu, Ezema, and Ogbodo (2020), Covid 19 has shown more clearly the inequality in welfare and access to public health globally, as evidenced by the higher number of underprivileged people who have contracted the deadly virus. UGC broadcast by CNN entitled "Viral Video of Citizens Get Injection Without Pressed" became the witness to the inequality in the implementation of vaccines in the field. Likewise, UGC entitled "Spokesperson of the DPRD (regional house of representative) Ketapang danced Without Health Protocol", which was broadcast by Metro TV, also put forward the narrative of public officials' disobedience to the rules during the pandemic.

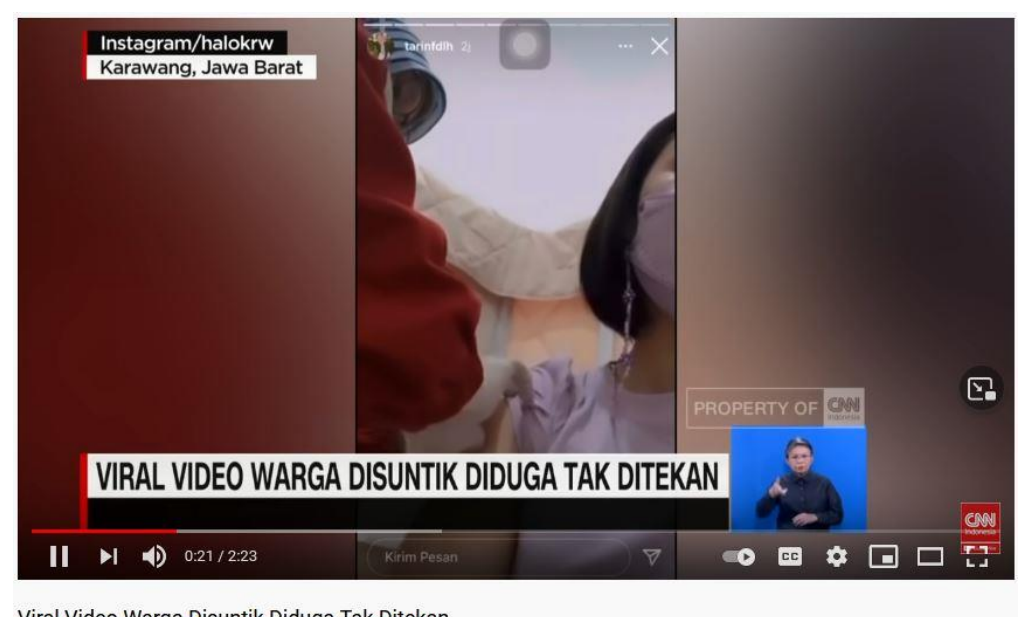

Figure 2. UGC titled "Viral Video of Citizens Getting Injected but Unstressed" which was broadcast again by CNN on July 15, 2021

In addition, information about the sadness or difficulties experienced by a number of residents during the pandemic is one of the main narratives used. The information is categorized as fatality framing and severity framing, which are an important part of the practice of empathy journalism. The news framing that is displayed through amateur recordings is more directed at encouraging audience empathy. This framing is also supported by the nuances of the video, which is more subjective and authentic so that it presents a more emotional picture to the audience. For example, the UGC entitled "Grandfather Pedal Bike 15 Kilometers for the Covid 19 Vaccine", which was broadcast by Kompas TV, emphasized information connected with moral values to arouse public sympathy, solidarity, or empathy. This information also encourages more constructive pandemic reporting/reporting.

However, from observations made on UGC broadcasts by TV stations, not much content was found that leads to information about health or crisis management or awareness framing. TV stations still rarely elaborate on information sourced from UGC with health education for the community and which is solution-oriented. In addition, UGC broadcast by news TV stations in Indonesia is still limited to prioritizing content currently viral in cyberspace and is mainly dominated by conflict framing, fear, and panic. One of the UGC's entitled "Viral Covid-19 Patient's Coffin Forcefully Opened by Citizens" was re-aired by CNN. The dominance of such news can increase residents' 
concerns or fears regarding the condition of handling the pandemic. If done excessively, it can actually hinder the handling of the health crisis. Likewise, the UGC content entitled "Forcibly Take the Body in Bondowoso" is broadcast by TV One which, is still dominated by negative consequences which are increasingly causing concern in the community and have not offered any solutions. As a result, the UGC's presentation seems only to pursue sensationalism and is only conflict-oriented or destructive in the effort to implement outstanding journalism during a pandemic. Likewise, the UGC content entitled "Forcibly Take the Body in Bondowoso" which is broadcast by TV One, is still dominated by negative consequences that are increasingly causing concern in the community and have not offered any solutions. As a result, the UGC's presentation seems only to pursue sensationalism and is only conflict-oriented or destructive in the effort to implement ideal journalism during a pandemic. Likewise, the UGC content entitled "Forcibly Take the Body in Bondowoso" is broadcast by TV One, which is still dominated by negative consequences that are increasingly causing concern in the community and have not offered any solutions. As a result, the UGC's presentation seems only to pursue sensationalism and is only conflict-oriented or destructive in the effort to implement ideal journalism during a pandemic. Prajarto (2008) states that information in a disaster or crisis situation should reduce fear.

\section{Conclusion}

UGC has made it possible for ordinary people to contribute to mainstream media, particularly in coverage of crises such as during the Covid-19 pandemic. In a pessimistic view of the use of UGC by news television, in fact, amateur content from the community helps journalists work to present actual information from news sources that are difficult for journalists to access during a pandemic. This study indicates that there is a shift in some of the logic of professionalism to the logic of adaptability by 24hour news TV stations in Indonesia in broadcasting UGC. When pursuing actuality, newsrooms often ignore verification or re-clarification to the main subject of the news or to the citizens who produce UGC. However, the newsroom is still trying to complete UGC information with information from several related parties. The shift in the logic of professionalism can also be seen in UGC broadcasts, which are technically far from professional or still amateurish. However, at the same time, UGC comes with emotional nuance and sincerity that has rarely been seen by news packages produced by professional journalists. This study also shows the positive effect of broadcasting UGC by news television stations in the application of constructive pandemic journalism, mainly because UGC encourages more inclusive framing and encourages empathy and solidarity. However, the destructive potential of broadcasting UGC still exists when newsrooms still prioritize sensationalism and conflict in reporting, especially those containing UGC. News TV stations should not only broadcast UGC, which is viral and sensational in cyberspace but also need to pay attention to educational and informative content to be able to carry out the role of the media optimally. Further research on this issue is still very much needed to get a more concrete and in-depth picture of UGC use by news TV stations during the pandemic. 


\section{References}

Ahva, L., \& Hellman, M. (2015). Citizen Eyewitness Images And Audience Engagement In Crisis Coverage. International Communication Gazette, 77(7), 668-681.

Andén-Papadopoulos, K. (2013). Media Witnessing and the 'Crowd-Sourced Video Revolution'. Visual Communication, 12(3), 341-357.

Bock, M. A. (2012). Citizen Video Journalists and Authority in Narrative: Reviving the Role of The Witness. Journalism, 13(5), 639-653.

Clark, R. P. (2009). Who Is the Fifth Estate and What Is Its Role in Journalism's Future? The Poynter Institute.

Cnnindonesia (2021). Viral Ruang Isolasi Tak Ada Naskes. Retrieved From Https://Www.Youtube.Com/Watch?V=Gejxmrmh5na\&T=15s

Cnnindonesia. (2021). Viral Video Warga Disuntik Tak Ditekan. Retrieved From Https://Www.Youtube.Com/Watch?V=B_Hptlmhjxw

Colistra, R., Buchman, E., \& Duvall, K. (2017). User-Generated Content and Television News Stations: Perceptions, Policies, and Uses. Electronic News, 11(3), 123-144.

Cottle, S., \& Ashton, M. (1999). From BBC Newsroom To BBC Newscentre: On Changing Technology And Journalist Practices. Convergence, 5(3), 22-43.

Couldry, N. (2012). Media, Society, World: Social Theory and Digital Media Practice: Polity.

Daugherty, T., Eastin, M. S., \& Bright, L. (2008). Exploring Consumer Motivations for Creating User-Generated Content. Journal of Interactive Advertising, 8(2), 16-25.

Domingo, D., Quandt, T., Heinonen, A., Paulussen, S., Singer, J. B., \& Vujnovic, M. (2008). Participatory Journalism Practices in the Media and Beyond: An International Comparative Study of Initiatives in Online Newspapers. Journalism Practice, 2(3), 326-342.

Haddow, G., \& Haddow, K. (2013). Disaster Communications in a Changing Media World: Butterworth-Heinemann.

Hayati, H. N., \& Yoedtadi, M. G. (2020). Konstruksi Berita Covid-19 Di Kompas. Com Dan Tribunnews. Com. Koneksi, 4(2), 243-250.

Budi HH, S. (2012). Komunikasi Bencana: Aspek Sistem (Koordinasi, Informasi Dan Kerjasama). Jurnal ASPIKOM, 1(4), 362-372.

Kompastv (2021). Antrian Pasien Covid 19 Di RSKD Hingga Koridor. Retrieved From Https://Www.Youtube.Com/Watch?V=Tagb-ZU7g9Y

Kompastv (2021). Kakek Berusia 67 Tahun Rela Kayuh Sepeda 15 Km Demi Vaksinasi. Retrieved

From

Https://Www. Youtube.Com/Watch?V=Nfvosx9kwus\&T=35s

Lestari, P. (2019). Perspektif Komunikasi Bencana. In: PT. Kanisius.

Matthews, J. (2013). 15 Journalists and Their Sources. Journalism: New Challenges, 242.

Mccosker, A. (2013). De-Framing Disaster: Affective Encounters with Raw and Autonomous Media. Continuum, 27(3), 382-396.

Metrotv (2021). Viral Pasien Covid-19 Diusir Saat Isolasi Mandiri, Lurah Batununggal: Ada Salah Paham. $\quad$ Retrieved Https://Www.Youtube.Com/Watch?V=V11 robazoxe

Metrotv (2021). Ketua DPRD Ketapang Joged Tanpa Prokes. Retrieved From Https://Www.Metrotvnews.Com/Play/Nnjcdqmw-Viral-Ketua-Dprd-KetapangJoget-Tanpa-Prokes 
Nwakpu, E. S., Ezema, V. O., \& Ogbodo, J. N. (2020). Nigeria Media Framing Of Coronavirus Pandemic and Audience Response. Health Promotion Perspectives, 10(3), 192.

Pamela, S. J., \& Stephen, R. D. (1996). Mediating the Message: Theories of Influences on Mass Media Content. In: New York: Longman Publishing Group.

Parahita, G. (2020). Lima Dimensi Jurnalisme Krisis COVID-19. Tata Kelola.

Perreault, M. F., \& Perreault, G. P. (2021). Journalists on COVID-19 Journalism: Communication Ecology of Pandemic Reporting. American Behavioral Scientist, 65(7), 976-991.

Prajarto, N. (2008). Bencana, Informasi Dan Keterlibatan Media. Jurnal Ilmu Sosial Dan Ilmu Politik, 11(3), 37528.

Rauchfleisch, A., Artho, X., Metag, J., Post, S., \& Schäfer, M. S. (2017). How Journalists Verify User-Generated Content During Terrorist Crises. Analyzing Twitter Communication during the Brussels Attacks. Social Media+ Society, 3(3), 2056305117717888.

Sushmita, C. I., Pawito, P., \& Rahmanto, A. N. (2021). Rumours And Infodemics: Journalist's Social Media Verification Practices during the Covid-19 Pandemic. Profetik: Jurnal Komunikasi, 14(1), 116-134.

Tait, S. (2008). Pornographies of Violence? Internet Spectatorship on Body Horror. Critical Studies in Media Communication, 25(1), 91-111.

Tvone (2021). Pasien Positive Covid 19 Dianiaya Warga Di Toba Sumut. Retrieved From Https://Www.Youtube.Com/Watch?V=5tbrb7cfmxm

Tvone (2021). Ambil Paksa Jenazah Di Bondowoso. Retrieved From Https://Www.Youtube.Com/Watch?V=Jgpnbjyod9e

Van Der Haak, B., Parks, M., \& Castells, M. (2012). The Future of Journalism: Networked Journalism. International Journal of Communication, 6, 16.

Vinanda, R. A. (2021). Jurnalis Dan Dinamika Proses Produksi Berita Pada Media Online Di Masa Pandemi Corona (Studi Kasus Produksi Berita Covid-19 Oleh Jurnalis Media Detik. Com, Tribunnews. Com, Suara. Com Dan VOI. Id). Universitas Gadjah Mada,

Wahl-Jorgensen, K., Williams, A., \& Wardle, C. (2010). Audience Views On UserGenerated Content: Exploring The Value Of News From The Bottom Up. Northern Lights: Film \& Media Studies Yearbook, 8(1), 177-194.

Wardle, Dubberley, S., \& Ma Pete Brown. (2014). Amateur Footage: A Global Study of User-Generated Content in TV and Online-News Output. Retrieved From

Williams, A., Wahl-Jorgensen, K., \& Wardle, C. (2011). 'More Real And Less Packaged': Audience Discourse On Amateur News Content And Its Effects On Journalism Practice.

Woda, B. E., Birowo, M. A., Vidiadari, I. S., \& Nuswantoro, R. (2021). Pandemic Journalism: A Study of Covid-19 News Coverage on Detik. Com. Jurnal ASPIKOM, 6(2), 235-249.

Zeller, F., \& Hermida, A. (2015). When Tradition Meets Immediacy And Interaction. The Integration of Social Media In Journalists' Everyday Practices. Sur Le Journalisme, About Journalism, Sobre Jornalismo, 4(1), 106-119. 